\title{
African American Father Involvement and Preschool Children's School Readiness*
}

By: Jason T. Downer and Julia L. Mendez

Downer, J. \& Mendez, J.L. (2005). African American father involvement and preschool children's school readiness. Early Education and Development, 16(3), 317-339.

Made available courtesy of Taylor \& Francis (Routledge):

http://www.tandf.co.uk/journals/titles/10409289.asp

***Note: Figures may be missing from this format of the document

\section{Abstract:}

A developmental ecological model was used to identify child attributes, father characteristics, and familial factors associated with multidimensional father involvement with preschool children enrolled in Head Start. The relations between father involvement and children's school readiness were also investigated. Eighty- five African American fathers and father figures were surveyed about their involvement in child care, home-based educational and school-based educational activities. Children's school readiness competencies were evaluated via teacher report or direct assessment. Father involvement in child care and home-based educational activities were predicted by different contextual factors and child attributes. Fathers were more involved in child care activities when they lived in a child's home and when a child was highly emotional. Fathers who perceived the existence of a strong parenting alliance reported more involvement in homebased educational activities. Father involvement in child care and home-based educational activities was associated with higher levels of children's emotion regulation. Findings are consistent with a contextual, multidimensional perspective of African American fathering and hold policy implications for fatherhood initiatives in the early childhood education field. Efforts to increase father involvement may be most effective when addressing the multitude of influences on fathering behavior and focusing on father-child activities that occur outside of the preschool setting.

\section{Article:}

\section{African American Father Involvement and Preschool Children's School Readiness}

The past two decades of research on young children's development have been characterized by a rising interest in the role of fatherhood. The impetus for this shift in empirical attention toward fathers has been marked by expanded conceptualization of the male role in families as well as increased awareness of their unique influence within the family (Mackey, 1998). Fathers assume a variety of family roles and in doing so make direct and indirect contributions to young children's development and preparation for school (Booth \& Crouter, 1998; Marsiglio, Amato, Day, \& Lamb, 2000; Pleck \& Masciadrelli, 2004). Recent educational policy has set a nationwide goal that all children begin school ready to learn (National Education Goals Panel,

\footnotetext{
* This research was conducted at the University of South Carolina and supported by a Head Start Scholar Grant from the Administration for Children and Families, Department of Health and Human Services awarded to the first author and a Head Start Quality Research Center Consortium grant awarded to the second author. We thank Harry Reese, Ogie White, Doré LaForett, Livy Fogle, and Erin Spelman for their assistance with data collection and Head Start families and staff for collaborating with our research team.
} 
1997). This mandate has created the need for more research regarding the complex factors that are related to low-income, minority children's school readiness and has opened the door for investigation in understudied areas, such as a father's role in promoting children's early learning.

The role of fathers in child development is a continually evolving concept that has resulted in different definitions of fatherhood and contributed to the perpetual struggle for precise, meaningful assessment of father involvement (Pleck \& Pleck, 1997). Contention persists regarding the most accurate way to measure fathering, whether it consists of counting the number of hours that fathers spend with their children, observing the quality of fathers' parenting during play, calculating fathers' financial contributions to their families, or simply referring to fathers as absent versus present (Lamb, 2000). Fatherhood theorizing in the 1970s and 80s was characterized by a narrow focus on any one of these fathering aspects, but has rapidly evolved to include a broadened, multidimensional perspective that recognizes the myriad of ways that fathers can contribute to families and child development (Lamb \& Tamis-LeMonda, 2004). Multi-faceted definitions of father involvement are increasingly being recognized as the gold standard for understanding fatherhood (Cabrera, TamisLeMonda, Bradley, Hofferth, \& Lamb, 2000; Tamis-LeMonda \& Cabrera, 2002).

A natural next step in developing a comprehensive, multidimensional model of fatherhood is to further examine the nuances of fathers' involvement with their children. Therefore, in the current study, father involvement is specifically explored during early childhood and across varied contexts, using Epstein's seminal model of parent involvement in young children's education (1996) as a guide for categorizing involvement into proximal and distal influences across home and school settings. Home parenting activities are distinctly separated into tasks that focus on basic child care needs and those that concentrate on establishing a positive learning environment for children. Parent involvement in home-based educational activities can also be differentiated from active participation in school-based activities that contribute to children's learning. Recent research efforts have empirically documented multiple dimensions of parent involvement (Fantuzzo, Tighe, \& Childs, 2000; Grolnick \& Slowiaczek, 1994), yet studies that simultaneously examine multiple domains of involvement remain infrequent. The present study defines father involvement in a comprehensive fashion, utilizing empirically derived dimensions of home- and school-based involvement in learning activities (Fantuzzo et al., 2000), in addition to capturing basic child care activities performed by fathers at home (Administration for Children and Families [ACF], 2002).

A major limitation of the father involvement literature relates to the generalizability of these constructs, largely because research on fathering behavior with young children has focused heavily on White middle-class samples (Marsiglio, Day, \& Lamb, 2000; Roggman, Fitzgerald, Bradley, \& Raikes, 2002). Investigations involving culturally and linguistically diverse groups from a range of socioeconomic status are presently lacking for many areas of research, yet overlooking such issues with ethnic minority families poses unique problems for understanding the validity of data regarding fathering behavior. For example, African American fathers are faced with unique, longstanding challenges in the United States, including systematic racism and discrimination, reduced economic opportunity, and limited access to social rewards (Billingsley, 1992; Swanson \& Spencer, 1991). Although African American men have historically been labeled as absent and missing from families (Moynihan, 1965; Popenoe, 1996), recent evidence 
refutes such broad misrepresentations of African American fathers (Coley, 2001; Hofferth, 2003).

Studies of family functioning reveal that African American fathers value their childrearing role (McAdoo, 1981, 1986; McLanahan \& Carlson, 2004), while role flexibility, in the form of shared duties between mothers and fathers, is a consistent strength with African American families (Billingsley, 1992; Jarrett, Roy \& Burton, 2002). Evidence also exists to suggest that African American communities place value on fathers remaining involved with children regardless of residential status (Coley, 2001). In addition, given that strong kinship networks are common within African American families, children often experience male involvement beyond that of their biological father (Coley, 2001; Jarrett et al., 2002). The unique qualities of African American fatherhood require intra-group investigations that examine emic aspects of family functioning, in order to reveal individual differences within low-income and minority families (Garcia Coll et al., 1996; Mendez, Fantuzzo, \& Cicchetti, 2002; Spencer, 1990). A competencebased, empirical approach to studying fathers in these communities may yield new data regarding fathers' contributions to children's success prior to and during the transition to school.

The parent-child relationship and parental involvement in education are key determinants of children's positive development (Epstein, 1996; Grolnick \& Slowiaczek, 1994). Despite common acceptance of the assumption that involved fathers provide important contributions to their children's development, paternal impact on young children's outcomes has been understudied in low-income, minority families (Lamb \& Tamis-LeMonda, 2004) and when compared to inquiries into mothers' influences (Coltrane \& Parke, 1998). In a review of African American fathering studies, Coley (2001) indicated that paternal involvement is most consistently linked with children's positive cognitive development and school functioning, though it also appears to be associated with socioemotional development. For example, lowincome African American households that included a father who provided financial contributions, was satisfied with parenting and showed nurturance during play had children with greater cognitive and receptive language skills (Black, Dubowitz \& Starr, 1999). Father presence and responsiveness during play have also been associated with better cognitive competence for urban toddlers (Shannon, Tamis-LeMonda, London, \& Cabrera, 2002), while father presence, supportiveness, sensitivity, and parenting satisfaction have been related to reduced child behavior problems, better socialization, and a stronger sense of perceived social competence (Black et al., 1999; Dubowitz et al., 2001; Kelley, Smith, Green, Berndt, \& Rogers, 1998). Though yet to be established in a low-income, preschool sample, there is emerging evidence that father behavior is linked to emotional regulatory abilities for slightly older children in middle class families (McDowell, Kim, O’Neil, \& Parke, 2002).

For young children preparing to enter primary school, "school readiness" has become the child outcome construct of choice. However, limited agreement has been reached concerning what school readiness encompasses and how it should be accurately assessed (Meisels, 1999). Raver and Zigler (1997) argue that cognitive competence must be joined by social competence in order to achieve a more holistic perspective of children's readiness to learn in a school setting. In our framework, we consider receptive language, peer play competence and emotion regulation to be related but distinct components of school readiness and utilize measurement tools that have been proven reliable and valid with low-income, minority preschoolers (Mendez et al., 2002). 
There is considerable support for the perspective that father involvement and children's school readiness are complexly determined. An ecological approach to paternal involvement provides a multi-systemic perspective on the determinants of fathers' roles and the cognitive, affective and behavioral manifestations of these roles. As outlined by Doherty, Kouneski and Erickson (1998), child attributes, mother and father characteristics, and the co-parenting relationship can all affect fathers' involvement in their children's lives. In addition, although the ecology of child development includes influential factors that are proximal and distal, proximal factors such as the father-child relationship are theorized to have the most direct impact on development (Sameroff \& Fiese, 2000).

Of particular interest in the present study was a model reflecting three elements of the context of fatherhood - child attributes, father characteristics, and familial characteristics - that may affect a father's involvement with a preschool child. Child attributes, such as gender and temperament, have been implicated in the prediction of fathers' parenting behavior. Fathers appear to be more involved with sons than daughters (Harris \& Morgan, 1991) and demonstrate increased sexstereotyped interactions with sons over time (Lewis, 1997). In terms of temperament, fathers have been observed in more child care activities with temperamentally difficult children than easy children, though the quality of these interactions was not necessarily high (Volling \& Belsky, 1991).

Individual father characteristics are also typically associated with fathers' involvement in parenting young children. Positive relations exist among fathers' perceived competence, role satisfaction and involvement (Ihinger-Tallman, Pasley, \& Buehler, 1993), as does an association between increased levels of paternal self-esteem and responsiveness during father- child interactions in African American families (Fagan, 1996). In addition, biological and stepfathers in two-parent families who believe that a father's role is important in child development tend to spend more time with and take more responsibility for their children (Hofferth, 2003). Findings in regards to the association between father involvement and men's employment status are mixed and in need of clarification. There appears to be more concurrent and stable involvement by urban African American fathers and unwed, low-income fathers who are employed (Coley \& Chase-Lansdale, 1999; McLanahan \& Carlson, 2004), which could be related to maternal gatekeeping (Coley, 2001). However, the opposite pattern has also been suggested with reduced involvement by fathers with busy work schedules (Coltrane, 1996).

The father-mother relationship is a salient family level influence on father involvement, as are household living arrangements. Maternal endorsement of paternal involvement's benefits is associated with increased father engagement (Palkovitz, 1984), while mothers' reluctance to believe in a father's positive influence correlates with less father involvement (Allen \& Hawkins, 1999; Deluccie, 1995). Specifically, a positive, collaborative coparenting relationship between fathers and mothers, whether it occurs in or outside of a marital arrangement, is associated with increased paternal involvement (Coley \& Chase-Lansdale, 1999; Tanfer \& Mott, 1997). Additionally, fathers living in the home of a child are more likely to be involved in a variety of parenting activities than fathers living outside of the child's household (Pleck, 1997). Child, father and familial elements of a father's ecology have been represented individually in past research endeavors, but less often included in a comprehensive manner. A developmental 
ecological model that simultaneously considers all levels of influence on involvement is necessary to advance our scientific inquiry regarding African American fatherhood.

The purpose of the present study was to identify family system and contextual factors that are associated with low-income, African American fathers' involvement in early learning experiences and examine how this involvement is related to young children's development. We purposefully sampled biological fathers and "social fathers" who were involved with children enrolled in Head Start (e.g., mother's partner, uncles, older brothers, grandfathers, stepfathers) in order to capture the diversity of fatherhood experience represented in African American families. In addition, father involvement was considered to encompass three distinct fathering activities that support and contribute to children's learning: general child care tasks, home-based educational activities, and school-based educational activities. In the spirit of applying a contextual framework to the father-child relationship, the present study investigated child, father and familial factors - child gender and temperament, fathers' employment status and parenting efficacy, and household living arrangements and the parenting alliance - in relation to the multiple aspects of father involvement (e.g., child care, home-based educational, and schoolbased educational activities), while jointly exploring the association between involvement and children's school readiness (e.g., receptive language, peer play competence, and emotion regulation). Three specific research questions are addressed:

1. What types of activities do low-income, African American fathers engage in with their preschool children at home and in Head Start?

2. Are child, father and familial elements of a father's ecological context related to and predictive of his involvement in child care, home-based educational and school-based educational activities?

3. Is a father's involvement in diverse early learning experiences associated with children's school readiness competencies in preschool?

Fathers are expected to report a variety of involvement activities with their children at home and school, including child care and educational tasks. In general, the combination of child attributes, father characteristics and familial elements are expected to predict the different dimensions of father involvement. Specifically, fathers are expected to report more involvement with male and temperamentally difficult children. They are also expected to report greater involvement when experiencing employment and perceiving their role in children's education to be important. In regards to family, more positive perceptions of the parenting alliance and a father's presence in the child's home are anticipated to predict greater involvement. Finally, it is hypothesized that father involvement will be positively related to children's emotional regulation, peer play competence and receptive language.

\section{Method}

\section{Participants}

Fathers of 3-, 4- and 5-year-old children were recruited from four Head Start centers in the greater metropolitan area of a southeastern United States city. For inclusion in the project as a father, men needed to indicate that they met one of three criteria. They had to be a biological father living in child's household, a biological father whom the child had seen once or more in the past year, or a male reported by the child's primary caregiver to be "like a father" to the child. These criteria were based on similar questions used in the Head Start Family and Child 
Experiences Survey (Administration for Children and Families, 1997) to identify father and father figure involvement. Direct recruitment of fathers and families occurred in person during center-based activities, over the phone or by a mail-out targeting men involved with the preschool children sent via children's book bags. Of 365 families contacted in this manner, 175 did not respond to survey packets sent home, 83 were unreachable (e.g., disconnected phone, child left school), 17 indicated no interest in participating, and 5 did not meet criteria for father involvement. As a result, eighty-five African American fathers with a child attending one of the four targeted Head Start centers consented to participate in the study. For their time and effort, fathers received a small honorarium. Complete school readiness data were collected for 74 of 85 children in the sample; partial readiness data were available for 11 children due to a variety of circumstances, including lack of child availability.

The sample of children included 44 boys and 41 girls. The mean age of the children was 55.48 months $(S D=7.17)$ with a range of 40 to 68 months. The mean age of fathers was 30.84 years $(S D=7.45)$ with a range of 18 to 53 years. Fathers' relationships with the children were most commonly biological father (70.6\%) and stepfather (9.4\%), though other relationships also existed (See Table 1). In terms of fathers' relationships with the children's mothers, marriage (37.6\%) and living together but not married (25.9\%) were the most frequently reported category (See Table 1). Fathers primarily indicated that they lived in the home of the target child (71.8\%), worked full-time (71.8\%) and held a high school diploma or equivalent (50.6\%). Nonresidential fathers reported living no further than 20 miles away from the target child $(M=9.15, S D=6.60)$ and in all cases indicated that they were providing some form of financial support for the child.

\section{Procedure}

The present study investigates the relation among child, father and familial factors, different measures of father involvement, and children's school readiness. Within the context of a preexisting, collaborative partnership between local Head Start centers and university researchers, recruitment of fathers occurred in person during center-based activities and then by phone or a mail-out using children's book bags. Fathers consented and completed 
Table 1.

Father Demographic Information

\begin{tabular}{|c|c|c|}
\hline & Frequency & Percent \\
\hline \multicolumn{3}{|l|}{ Relationship to mother } \\
\hline Married & 32 & 37.6 \\
\hline Living together & 22 & 25.9 \\
\hline Other relationship & 14 & 16.5 \\
\hline Dating & 12 & 14.1 \\
\hline Separated & 3 & 3.5 \\
\hline Divorced & 1 & 1.2 \\
\hline \multicolumn{3}{|l|}{ Relationship to child } \\
\hline Biological father & 60 & 70.6 \\
\hline Other father figure & 11 & 13.0 \\
\hline Stepfather & 8 & 9.4 \\
\hline Uncle & 4 & 4.7 \\
\hline Grandfather & 1 & 1.2 \\
\hline \multicolumn{3}{|l|}{ Educational attainment } \\
\hline High school diploma or equivalent & 43 & 50.6 \\
\hline Some college & 20 & 23.5 \\
\hline Middle to some high school & 8 & 9.4 \\
\hline College degree & 6 & 7.1 \\
\hline Vocational school & 5 & 5.9 \\
\hline Some graduate school & 2 & 2.4 \\
\hline \multicolumn{3}{|l|}{ Employment status } \\
\hline Full-time & 61 & 71.8 \\
\hline Part-time & 7 & 8.2 \\
\hline Unemployed & 7 & 8.2 \\
\hline Disability & 4 & 4.7 \\
\hline Self-employed & 3 & 3.5 \\
\hline Student & 2 & 2.4 \\
\hline
\end{tabular}

$N=84$

self-report surveys at their child's Head Start center or at home to provide information about the quantity and types of interaction between themselves and their children enrolled in Head Start. Fathers were continually recruited over 18 months and data for each father-child dyad, including teacher ratings, were collected within a one month interval. Teachers provided assessments of temperament, emotion regulation and play interaction for each child, while trained graduate students directly assessed children's language development. 


\section{Measures}

The measures for this project were selected based on their previous use with low-income, African American adults and young children in order to assure their appropriateness for this Head Start sample. Several measures were developed or validated through Head Start grantfunded research projects (Coolahan, Fantuzzo, Mendez, \& McDermott, 2000; Fantuzzo, Mendez, \& Tighe, 1998; Mendez, McDermott, \& Fantuzzo, 2002), while others have been specifically validated for use with father (Abidin \& Konold, 1999) or low-income, African American samples (Dunn \& Dunn, 1997).

\section{Child, Father, and Family Characteristics}

In questionnaire form, fathers were asked to supply their age, education level, employment status, relationship to Head Start child, status of relationship to child's mother, current marital status, and race/ethnicity. Fathers were also asked to report the Head Start child's age, sex, and race/ethnicity, which were then verified with Head Start center records.

Teachers rated children's negative emotional intensity using the Temperament Assessment Battery for Children (Martin, 1988). The TABC is available for teachers to rate basic temperament characteristics of children 3-7 years of age. Test-retest reliability of ratings over six months ranged from .70-.80, and Cronbach's alpha coefficients for the teacher subscales have ranged from .69-.86 (Martin, 1988). The teacher form (T-TABC) consists of 48 items describing child behaviors that occur in the school setting. Each item is rated on a 7-point scale ranging from never to always. The Emotional Intensity subscale is one for which adequate internal consistency exists when rating low-income, African American children (Mendez et al., 2002). A higher score is indicative of a child who experiences emotions more intensely than same-age peers, with a particular emphasis on the expression of negative affect (i.e., anger, frustration).

To assess a father's perceived impact on education the About Being a Parent Scale (ABPS; Wentzel, 1993) was used. The 5-item ABPS was adapted from a measure of teacher efficacy developed by Hoy and Woolfolk in 1993 (Seefeldt, Denton, Galper, \& Younoszai, 1998). It assesses parents' beliefs about their ability to influence their children's educational outcomes and has shown adequate internal consistency at an $\mathrm{a}=.86$ (Wentzel, 1993). The ABPS includes items such as, "Even a parent with good teaching abilities cannot teach his or her child as well as a classroom teacher," and "Parents do not have a powerful influence on children's achievement when all factors are considered." Items were modified to read "father" rather than "parent" for this project. Fathers rated each item on a six-point Likert scale from 1 (strongly disagree) to 6 (strongly agree). The scale was reversed so that higher scores indicate the belief that fathers can effectively impact children's achievement. In the current sample, this scale demonstrated adequate internal consistency at an $\mathrm{a}=.83$.

The Parenting Alliance Measure (PAM; Abidin \& Konold, 1999) is a 20-item, self- report assessment of a parent's perspective on his ability to cooperate with his child's other parent to meet the developmental needs of the child. A strong parenting alliance is characterized by mutual investment in the child, value and respect for the other parent's input and involvement, and a desire to communicate with the other parent about the child. The PAM has demonstrated a high degree of internal consistency $(\mathrm{a}=.97)$ and adequate criterion-related validity for fathers 
(Abidin \& Konold, 1999). High scores on the PAM indicate perceptions of greater cooperation between parents. In this sample, internal consistency was high at an a $=.92$.

\section{Father Involvement}

The Activities with Your Child (AYC) section of the Head Start Family and Child Experiences Survey (Administration for Children and Families, 1997) was modified slightly to create a measure of father involvement in a variety of childrearing activities at home and in the community, such as "involved her in household chores" and "gone to a movie." There are two basic sets of items: one referring to activities in the past week and another referring to activities during the past month. All items were answered with one of three forced choices: no, once or twice, and three or more times. A high total score, inclusive of weekly and monthly items, is indicative of more father involvement in child care activities. Internal consistency of the AYC was determined to be high $(\mathrm{a}=.90)$.

The Family Involvement Questionnaire (FIQ; Fantuzzo et al., 2000) is a multidimensional measure of caregiver involvement in early childhood education. The FIQ was developed and field-tested with low-income families of preschoolers in Head Start, assuring its validity for use with the current target population. It has also met multiple construct validity criteria and consists of three empirically derived scales: School-Based Involvement, Home-Based Involvement, and Home-School Conferencing (Fantuzzo et al., 2000). The School-Based Involvement scale assesses parents' participation in activities such as volunteering in the classroom and going on class trips with the children. The Home-Based Involvement scale assesses behaviors parents engage in at home to promote learning, including the provision of learning materials and initiation of learning activities. For this project, items for the Home- School Conferencing scale were not utilized. Higher scores indicate higher rates of father involvement in home-based educational activities and school-based educational activities. Internal consistency for the School-Based and Home-Based Involvement scales were adequate at an $\mathrm{a}=.81$ and $\mathrm{a}=.89$, respectively.

\section{School Readiness}

The Peabody Picture Vocabulary Test - Third Edition (PPVT-III; Dunn \& Dunn, 1997) is a commonly used outcome indicator for Head Start children's receptive language development. Internal consistency is typically strong, with Spearman-Brown split half reliability ranging from .92-.98. For a one-month interval, test-retest reliability ranged from .91-.93. Construct and criterion-related validity have been demonstrated through correlations with the Wechsler Intellectual Quotients (.82-.92). The Third Edition is the latest version, including a more normative sample with adequate representation of minority children.

The Penn Interactive Peer Play Scale (PIPPS; Coolahan et al., 2000) was developed in collaboration with Head Start teachers and parents to describe peer play interactions of African American children. The 32-item teacher questionnaire was used for this project, which identifies common play behaviors that facilitate or interfere with prosocial peer interactions in the classroom. Ecological and concurrent validity of the PIPPS have been established with urban African American children in Head Start centers (Fantuzzo, Coolahan, Mendez, McDermott, \& Sutton-Smith, 1998). Multiple factor analytic studies (Coolahan et al., 2000; Fantuzzo et al., 1998) have yielded three underlying dimensions of children's play behaviors: Play Interaction, 
Play Disruption and Play Disconnection. The Play Interaction factor captures children's play strengths including creative and cooperative behaviors that promote successful peer interactions. Given the competency model of child development utilized in this study, only the Play Interaction scale was used in analyses with higher scores indicating that a child has more peer play interaction strengths. Internal consistency of the Play Interaction scale was adequate $(\mathrm{a}=$ $.80)$.

As an assessment of children's self-regulation, the Emotion Regulation Checklist (ERC; Shields \& Cicchetti, 1997) was used to target young children's affective lability, intensity, valence, flexibility, and situational appropriateness. The ERC is a 24-item, other-report measure with items such as "Is able to delay gratification," which can be rated on a 4-point Likert scale from 1 (rarely/never) to 4 (almost always). Convergent and discriminant validity have been demonstrated with other established measures of affect regulation (Shields \& Cicchetti, 1997). Factor analyses have yielded two subscales for the ERC, including Lability/ Negativity and Emotion Regulation. Teachers completed the ERC for this project and only the competencyfocused emotion regulation construct was utilized in analyses. Higher scores indicate increased ability to regulate emotions. Internal consistency of the ERC was adequate $(a=.83)$.

\section{Data Analysis Plan}

The aim of this investigation was threefold: to describe African American fathers and their involvement in early learning experiences; predict involvement using a contextual model that included child, father and familial factors; and examine associations among involvement and children's school readiness. Descriptive analyses were utilized to provide an overall picture of the sample, while Table 2 presents the means and standard deviations for all continuous variables used in the data analyses. As a first step toward determining the strength and direction of associations among variables, Pearson product moment correlations were calculated between continuous variables, while point biserial correlations were calculated when one variable was dichotomous. Hierarchical regression analyses were conducted to test hypotheses about the prediction of father involvement based on child, father and familial elements of their ecological context. Preliminary analyses indicated no mean differences between biological and nonbiological fathers in regards to self-reported involvement; therefore, all men in the sample, regardless of their relationship with the target child, were included in the following analyses.

\section{Results}

\section{Description of Father Involvement}

Fathers reported participating in a wide variety of child care activities with their children. The most common weekly activities included playing with toys or games indoors $(\mathrm{M}=2.55, \mathrm{SD}=$ $.63)$, talking about what happened at Head Start $(\mathrm{M}=2.55, \mathrm{SD}=.68)$, taking child 
Table 2.

Means and Standard Deviations for Study Variables

\begin{tabular}{|l|c|c|}
\hline Variable & $M$ & $S D$ \\
\hline Child emotionality & 20.40 & 3.38 \\
Fathering efficacy & 24.83 & 5.51 \\
Parenting alliance & 55.63 & 8.11 \\
Child care activities & 46.36 & 9.27 \\
Home-based educational activities & 37.99 & 9.15 \\
School-based educational activities & 16.48 & 5.58 \\
Emotion regulation & 23.11 & 3.76 \\
Peer interaction & 46.46 & 9.70 \\
Receptive language & 85.36 & 12.10 \\
\hline
\end{tabular}

$N$ ranges from 65 to 83

along while doing errands $(M=2.54, S D=.63)$, and involving child in household chores $(M=$ $2.54, S D=.63)$. In contrast, the least common weekly activities were telling child a story $(M$ $=1.94, S D=.72)$ and working on arts and crafts $(M=1.71, S D=.74)$. In terms of activities in the past month, fathers reported that visiting a playground, park, or going on a picnic was quite common $(M=2.27, S D=.73)$, as were going to the mall $(M=2.10, S D=.78)$ and attending a church event $(M=2.05, S D=.82)$. The least common monthly activities were visiting the library $(M=1.35, S D=.57)$, going to a play or concert $(M=1.42, S D=.67)$, and visiting an art gallery, museum or historical site $(M=1.43, S D=.72)$.

In addition, on a measure that exclusively focuses on educational activities, fathers rated participation in home-based educational activities $(M=2.92, S D=.70)$ as occurring more frequently than school-based educational activities $(M=1.65, S D=.56), t(80)=18.16, p<$ .001 . For example, in terms of the home learning environment, they reported helping to maintain clear rules $(M=3.72, S D=.75)$ and a consistent morning and bedtime routine $(M=3.28, S D=$ 1.03). In contrast, fathers rarely reported direct, center-based involvement, such as planning classroom activities $(M=1.26, S D=.66)$ or volunteering in the classroom $(M=1.37, S D=.78)$.

\section{Contextual Correlates of Father Involvement}

The association between child, father, and familial factors, and multi-faceted father involvement was first examined using bivariate correlations (see Table 3). Fathers' child care activities occurred more frequently with children who demonstrated greater negative emotionality $(r=.24$, $p<.05)$ and when fathers lived with the Head Start child $(r=-.27, p<.05)$. In addition, fathers reported involvement in more home-based educational activities 


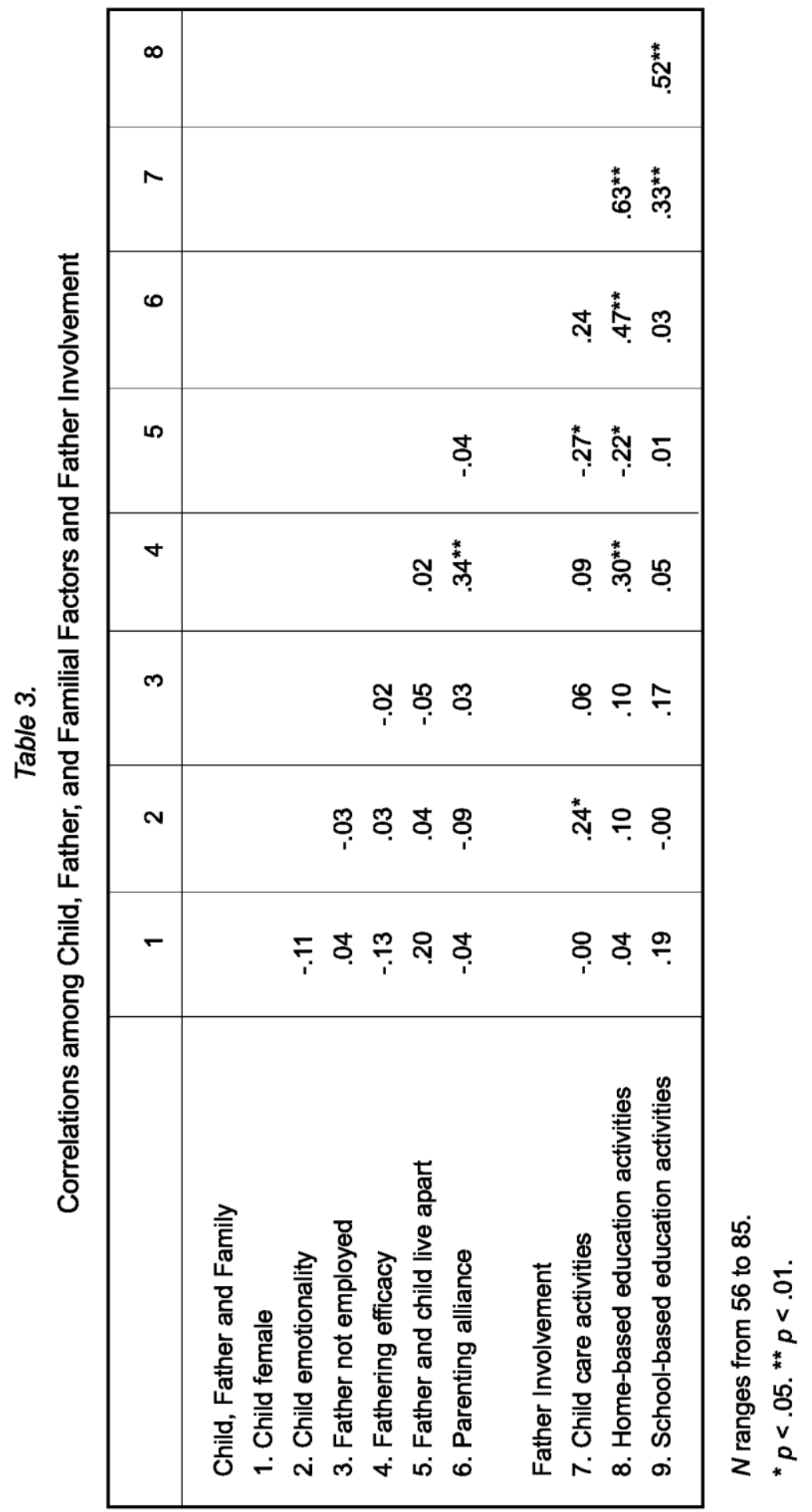

when they felt that their impact on children's educational outcomes was high $(r=.30, p<.01)$, they lived with the child $(r=-.22, p<.05)$, and their parenting alliance with the children's mothers was strong $(r=.47, p<.01)$. None of the child, father or familial factors was significantly correlated with school-based educational involvement. 


\section{Prediction of Father Involvement}

Three hierarchical regression analyses were conducted to predict father involvement (child care, home-based educational, and school-based educational activities) from child, father and familial factors. Predictors were entered in three separate blocks: Child (gender and temperament), Father (employment status and parenting efficacy) and Family (household living arrangements and parenting alliance). The results for these analyses are presented in Table 4 with block-level statistics underlined and estimated. Results are presented separately below for child care and home-based educational activities, focusing on whether child, father and familial predictors account for significant increments in explained variance. Father involvement in school-based educational activities was not significantly predicted by the set of elements from the contextual model, and therefore requires no further elaboration.

Table 4.

Prediction of Father Involvement Activities ${ }^{a}$

\begin{tabular}{|c|c|c|c|}
\hline & $\begin{array}{l}\text { Child Care } \\
\text { Activities }\end{array}$ & $\begin{array}{c}\text { Home-based } \\
\text { Educational } \\
\text { Activities }\end{array}$ & \begin{tabular}{|c} 
School-based \\
Educational \\
Activities
\end{tabular} \\
\hline Child ( $R^{2}$ change) & $\underline{0.11^{*}}$ & $\underline{0.06}$ & $\underline{0.04}$ \\
\hline Female & .07 & -.07 & .03 \\
\hline Emotionality & $.41^{* *}$ & $.30^{\star \star}$ & .22 \\
\hline Father ( $R^{2}$ change) & $\underline{0.02}$ & $\underline{0.10^{*}}$ & $\underline{0.04}$ \\
\hline Not employed & 10 & .10 & .20 \\
\hline Fathering efficacy & .02 & .20 & .03 \\
\hline Family ( $R^{2}$ change) & $\underline{0.15}^{\star *}$ & $\underline{0.19}^{\star \star *}$ & $\underline{0.01}$ \\
\hline Father and child live apart & $-.35^{\star \star}$ & -.18 & -.02 \\
\hline Parenting alliance & .22 & $.43^{\star \star \star}$ & .11 \\
\hline$R^{2}$ & $\underline{0.28}$ & $\underline{0.35}$ & $\underline{0.09}$ \\
\hline Model $F$ & $3.52^{\star *}$ & $4.85^{\star \star *}$ & 0.91 \\
\hline
\end{tabular}

$N=61$ for all models.

${ }^{*} p<.05 .{ }^{* *} p<.01 .{ }^{* * *} p<.001$.

a Standardized betas from final model

Father involvement in child care activities was significantly predicted by child, father and familial factors from a contextual model $(F[6,54]=3.52, p<.01)$. As shown in Table 4, significant results were found for the child and family blocks and in particular for child temperament and father residential status. Fathers whose children were rated by teachers as demonstrating negative emotional intensity reported more involvement in child care activities. Fathers who lived with their preschool child also reported more child care involvement. There were no significant findings for the father block in the child care activities regression model. 
Father involvement in home-based educational activities was also significantly predicted by the set of elements from the contextual model $(F[6,54]=4.85, p<.001)$, while the father and family blocks accounted for significant increments in explained variance (see Table 4). More specifically, fathers who perceived the existence of a strong parenting alliance reported more involvement in home-based educational activities. Though the child block as a whole did not contribute significantly to the regression model, children's temperament was a significant unique predictor of home-based educational activities. Fathers reported greater involvement in home-based educational activities when teachers had rated their children as demonstrating more negative emotional intensity.

\section{Relationship between Father Involvement and School Readiness}

Associations among father involvement and child school readiness measures are reported in Table 5. Fathers who reported being more involved in home-based educational $(r=.25, p<.05)$ and child care activities $(r=.22, p<.05)$ had children who were rated highly by teachers in the area of emotion regulation. There was a trend toward the same positive relationship with peer interaction, but not so for receptive language. Fathers' school-based educational involvement was not significantly associated with any of the school readiness variables.

Table 5.

Correlations among Father Involvement and School Readiness

\begin{tabular}{|c|c|c|c|}
\hline & $\begin{array}{c}\text { Emotion } \\
\text { Regulation }\end{array}$ & $\begin{array}{c}\text { Peer } \\
\text { Interaction }\end{array}$ & $\begin{array}{l}\text { Receptive } \\
\text { Language }\end{array}$ \\
\hline Child care activities & $.22^{*}$ & 16 & -.06 \\
\hline $\begin{array}{l}\text { Home-based } \\
\text { educational activities }\end{array}$ & $.25^{\star}$ & .17 & .01 \\
\hline $\begin{array}{l}\text { School-based } \\
\text { educational activities }\end{array}$ & .13 & -.07 & .08 \\
\hline
\end{tabular}

$N$ ranges from 70 to 80 .

${ }^{*} p<.05$.

\section{Discussion}

The purpose of the current study was to investigate fatherhood within a sample of low-income, African American men in order to contribute to an understanding of father involvement in learning experiences for preschool children. In doing so, much was learned about men who identified themselves as fathers of children enrolled in Head Start. Both biological and social fathers reported involvement in diverse interactions with their children, and their involvement was associated with children's emotion regulation skills. As expected, a contextual model of multifaceted father involvement was also confirmed, indicating that child, father and familial factors have implications for African American fathers' involvement in preschoolers' early learning experiences.

\section{Multidimensional Father Involvement}

Models of father involvement have evolved to shift toward more complex, expansive conceptualizations of fatherhood (Pleck \& Masciadrelli, 2004). In our sample, fathers most 
frequently reported participating in play-based interactions with their children, which closely parallels past research on father-child activities (Hofferth, Pleck, Stueve, Bianchi, \& Sayer, 2002; Yeung, Sandberg, Davis-Kean, \& Hofferth, 2001). However, consistent with a multidimensional perspective, fathers also reported involvement in a wide variety of activities that ranged from involving a child in household chores to attending a church event together. These fathers reported a frequency and range of involvement with their children that is in direct contrast to earlier literature that emphasized the absence of fathers in low-income, African American families (Popenoe, 1996).

By assessing involvement in multiple contexts, this study was able to document that fathers consistently reported much higher rates of engagement in home-based activities as compared to Head Start center-based involvement. For instance, fathers reported serving a key role at home in maintaining clear rules for their children and providing a consistent morning and bedtime routine, both of which have been conceptualized as key components of the home learning environment (Fantuzzo et al., 2000). In contrast, fathers rarely reported direct, school-based involvement such as planning classroom activities or school trips and volunteering at the centers. We tentatively conclude that this group of fathers supports their children's growth and education through engagement in child care activities and promotion of home-based learning experiences. These data imply that father involvement initiatives in early childhood education may have a greater impact by targeting father-child interactions outside of the classroom setting.

\section{Testing a Contextual Model of Father Involvement}

In line with our hypotheses, the findings provide support for an ecological-transactional perspective as applied to father involvement with preschool children in African American families. One compelling theme emerged from examination of child attributes, father characteristics, and family factors and their contributions to variance in father involvement. A similar pattern of significant associations was common for self-reported involvement in child care and home-based educational activities. Specifically, the role of the parenting alliance, father's living arrangements, efficacy about educational involvement, and child temperament were established as salient factors to consider in father involvement research.

Father-reported parenting alliance emerged as an important correlate to fathers' involvement in child care and home-based educational activities. Fathers reported more involvement when they also experienced a positive coparenting relationship with the child's mother. However, after accounting for child and father characteristics, the parenting alliance only remained a significant predictor for home-based educational activities. This finding replicates past research with White middle class families that found the parenting alliance to be a strong predictor of father involvement (McBride \& Rane, 1998) and extends this work to an African American sample with varied parental relationships or childrearing arrangements. Such results are also consistent with literature on marital relations that show conflict-ridden parental relationships are associated with lower father involvement (Furstenberg, 1995) and close parental relationships predict higher rates of paternal engagement with children (Coley \& Chase-Lansdale, 1999). Abidin (1992) argues that the parenting alliance is likely to be a better predictor of parent involvement than marital satisfaction or quality, because parents can be involved and function adequately in a parenting role without being satisfied with their personal relationship (Abidin \& Brunner, 1995). 
Coparenting within low-income, African American communities requires further investigation, given the prevalence of nonmarital childbearing among these families (Graefe \& Lichter, 1999).

In the present study, fathers' living arrangement was significantly associated with involvement at a bivariate level. Fathers who lived with their Head Start child were more likely to report greater involvement in child care and home-based educational activities. At first glance, these findings parallel what has been found in larger, national samples, such as the Family and Child Experiences Survey and Panel Study of Income Dynamics, which indicate that residential fathers have the highest rates of engagement and availability (ACF, 2002; Hofferth et al., 2002). And yet, after accounting for child and father characteristics, fathers' residential status remained a significant predictor for child care activities, but not for home-based educational activities. This finding suggests that sharing a residence may not be as essential to participating in home-based educational activities; in fact, these activities may be more accurately labeled community-based learning experiences. Our data indicate that non-residential fathers are engaging in educational activities with their children. Accounting for the total amount of interaction between children and fathers, regardless of residential status, is therefore likely to yield a better index of a father's contribution to child development.

Fathers' involvement in home-based educational activities was elevated when fathers believed that they played an important role in helping their children succeed educationally. Past research has established that various attitudes and beliefs held by fathers can be related to their level of involvement (Coley, 2001; Pleck, 1997), such as perceived skill at child care (Sanderson \& Thompson, 2002). This finding also parallels similar research completed with mothers, which indicated that parenting efficacy regarding children's education was related to mother's home involvement but not school involvement (Smith et al., 1997). Interestingly, a similar relationship was not found in this sample between home-based child care activities and fathers' perceived efficacy. This suggests that a father's belief in his influence over a child's educational success is likely to result in more educationally focused involvement at home, but not necessarily other types of child care involvement. And yet, in the full predictive model, fathering efficacy about education does not account for a unique portion of the variance in child care or home-based educational activities. This may in part be due to shared variance with coparenting quality, suggesting that many parents use a joint commitment to the education of their preschool children as a focus for forming a solid parenting alliance.

Consistent with past research (Volling \& Belsky, 1991), fathers were more involved when their children demonstrated greater negative emotionality. Conceptualizing father involvement as a transaction between parenting, child temperament, and co-parenting is an interesting area for further exploration. It is likely that fathers become more involved with their emotionally intense children because of the increased stress created by children with difficulty regulating emotion and complying with adult requests. Certainly our data do not speak to causal paths, but it is plausible that fathers are drawn into a greater parenting role as mothers request additional assistance with children who show difficult temperamental styles. Clearly, father involvement in early childhood requires an appreciation of the contextual factors, including child features, father variables, and familial elements, that together may influence fathers' behaviors. Continued use of an ecological model can inform policies that support and bolster fathers' role in children's early learning experiences. 


\section{Father Involvement and Children's School Readiness}

A central contribution of this study was the investigation of the relationship between father involvement and Head Start children's school readiness competencies. A link between father involvement and children's development has been established (Parke, 2002), though studies specifically involving low-income, minority fathers are less common (Coley, 2001). Correlations revealed that teacher-rated emotion regulation was greater for children when their fathers reported more involvement in child care and home-based educational activities. These same involvement dimensions were similarly related with children's peer play, though this association only approached significance. In contrast, fathers' involvement in school- based educational activities was unrelated to all measures of children's school readiness. No significant correlations between receptive language development and the different measures of father involvement in early learning experiences were found. This finding is perplexing given that studies investigating the influence of fathers on children's development have most consistently found an association between paternal involvement and cognitive or educational outcomes (Coley, 2001). Overall, findings provide tentative evidence of a relationship between father involvement and some aspects of school readiness, using a rigorous, teacher-report methodology. Different measures of cognitive and language outcomes should be explored, most notably emergent literacy and expressive language skills.

\section{Limitations and Summary}

This study provides insight into father involvement in a sample of low-income, African American families that can make valuable contributions to the growing field of fatherhood research. However, there are limitations that must be considered in interpreting findings and proposing future lines of inquiry. This study placed emphasis on direct recruitment of fathers with children enrolled in Head Start and being all-inclusive in determining fatherhood status. The selected sampling approach yielded a rich data set that included rarely acquired, self- report ratings of multidimensional father involvement within a diverse group of low-income, African American biological fathers and father figures. However, similar to past studies within the same population, a limited response rate during recruitment efforts led to a relatively unique sample of fathers, reducing generalizability of findings. For instance, in this sample, there were no significant differences in involvement between biological and non-biological fathers, while other large-scale fatherhood studies have found that there are distinct variations in the level of engagement with and responsibility for young children depending on a father's biological relationship with a child (Hofferth et al., 2002). It could be that there is an unmeasured selection factor, such as a father's ability to make financial contributions to the family, which resulted in biological and non-biological fathers being more alike than different in this sample. Although all families were considered to be low-income given criteria for enrollment in Head Start, fine-tuned examination of fathers' income within the family and its link to father involvement are deserving of further inquiry.

The present study joins an emerging body of literature on fatherhood that involves the recruitment of males to speak for themselves. These studies are essential to generating an appreciation of what defines parenting and involvement from an African American father's perspective. Given that the majority of parenting literature is comprised of research with mothers and children, fathers' viewpoints can inform how father involvement may differ from or parallel 
mothers' involvement in children's early learning experiences. Specific findings regarding the association between father and mother reports of paternal involvement have been mixed, either indicating that fathers over-report their involvement (Roggman et al., 2002) or that both reports are reliable (Hernandez, Coley, \& Morris, 2003). Further exploration of the relationship between maternal and paternal reports of father involvement is necessary, as is the assessment of children's perceptions of father contact, observed quality of the father-child relationship, and frequency of father-child contacts. Moreover, a participant recruitment strategy that targets families as a whole will likely produce a more balanced literature that examines the relative impact of mothers and fathers on present day childrearing.

The current correlational design can only speak to the relationships between key variables, rather than commenting on causal pathways. This conservative approach is appropriate given the relative exploratory nature of the project. However, even when father involvement was modestly related to a school readiness variable in this sample, it is unclear whether more involvement could be leading to improved child development or if children who were developing better had fathers who then became more involved. Developing recruitment and retention strategies that target African American men will facilitate the initiation and completion of longitudinal research that can deconstruct these developmental pathways.

In conclusion, this exploratory study of low-income, African American fathers provided new evidence to support a developmental ecological model of father involvement in early learning experiences. Father involvement in this sample was a complex, multidimensional construct influenced by both proximal and distal elements of a father's ecological context. Additionally, trends were noted in the direction of positive relationships between father involvement outside of the preschool setting and child school readiness competencies. Overall, findings provide valuable contributions to theorizing in regards to the role of low-income, African American fathers in preschoolers' development of school readiness skills.

References

Abidin, R. R. (1992). The determinants of parenting behavior. Journal of Clinical Child Psychology, 21, 407-412.

Abidin, R. R., \& Brunner, J. F. (1995). Development of a parenting alliance inventory. Journal of Clinical Child Psychology, 24, 31-40.

Abidin, R. R., \& Konold, T. R. (1999). Parenting alliance measure: Professional manual. Odessa, FL: Psychological Assessment Resources, Inc.

Administration for Children \& Families (2002). A descriptive study of Head Start families:

FACES technical report I. Retrieved from http://www.acf.dhhs.gov/programs/core/ ongoing_research/faces/technical_report/tech_title.html.

Administration for Children \& Families (1997). Head Start Family and Child Experiences

Survey. Retrieved from http://www.acf.dhhs.gov/programs/core/ongoing_research/ faces/hs_pdf/pifacs97.pdf.

Allen, S. M., \& Hawkins, A. J. (1999). Maternal gatekeeping: Mothers' beliefs and behaviors that inhibit greater father involvement in family work. Journal of Marriage and the Family, 61, 199-212.

Billingsley, A. (1992). Climbing Jacob's ladder: The enduring legacy of African-American families. New York: Simon \& Schuster. 
Black, M. M., Dubowitz, H., \& Starr, R. H. (1999). African American fathers in low income, urban families: Development, behavior, and home environment of their three-year-old children. Child Development, 70, 967-978.

Booth, A., \& Crouter, A. C. (1998). Men in families: When do they get involved? What difference does it make? Mahwah, NJ: Lawrence Erlbaum Associates.

Cabrera, N. J., Tamis-LeMonda, C. S., Bradley, R. H., Hofferth, S., \& Lamb, M. E. (2000).

Fatherhood in the twenty-first century. Child Development, 71, 127-136.

Coley, R. L. (2001). (In)visible men: Emerging research on low-income, unmarried, and minority fathers. American Psychologist, 56, 743-753.

Coley, R. L., \& Chase-Lansdale, P. L. (1999). Stability and change in paternal involvement among urban African American fathers. Journal of Family Psychology, 13, 416-435.

Coltrane, S. (1996). Family man. New York: Oxford University Press.

Coltrane, S., \& Parke, R. D. (1998, December). Reinventing fatherhood: Toward an historical understanding of continuity and change in men's family lives. Retrieved from http:// www.ncoff.gse.upenn.edu/wrkppr/parkepdf.pdf.

Coolahan, K. C., Fantuzzo, J., Mendez, J., \& McDermott, P. A. (2000). Preschool peer interactions and readiness to learn: Relationships between classroom peer play and learning behaviors and conduct. Journal of Educational Psychology, 92, 367-376.

DeLuccie, M. F. (1995). Mothers as gatekeepers: A model of maternal mediators of father involvement. The Journal of Genetic Psychology, 156, 115-13 1.

Doherty, W. J., Kouneski, E. F., \& Erickson, M. F. (1998). Responsible fathering: An overview and conceptual framework. Journal of Marriage and the Family, 60, 277-292.

Dubowitz, H., Black, M. M., Cox, C. E., Kerr, M. A., Litrownik, A. J., Radhakrishna, A., English, D. J., Schneider, M. W., \& Runyan, D. K. (2001). Father involvement and children's functioning at age 6 years: A multisite study. Child Maltreatment, 6, 300-309.

Dunn, L. M., \& Dunn, L. M. (1997). Peabody Picture Vocabulary Test-Third Edition. Circle Pines, MN: American Guidance Service, Inc.

Epstein, J. L. (1996). Perspectives and previews on research and policy for school, family, and community partnerships. In A. Booth \& J. F. Dunn (Eds.), Family-school links: How do they affect educational outcomes? (pp. 209-246).

Fagan, J. (1996). A preliminary study of low-income African American fathers' play interactions with preschool-age children. Journal of Black Psychology, 22, 7-19.

Fantuzzo, J., Coolahan, K., Mendez, J., McDermott, P., Sutton-Smith, B. (1998). Contextuallyrelevant validation of peer play constructs with African American Head Start children: Penn Interactive Peer Play Scale. Early Childhood Research Quarterly, 13, 411-431.

Fantuzzo, J., Mendez, J., \& Tighe, E. (1998). Parental assessment of peer play: Development and validation of the parent version of the Penn Interactive Peer Play Scale. Early Childhood Research Quarterly, 13, 655-672.

Fantuzzo, J., Tighe, E., \& Childs, S. (2000). Family Involvement Questionnaire: A multivariate assessment of family participation in early childhood education. Journal of Educational Psychology, 92, 367-376.

Furstenberg, F. F. (1995). Fathering in the inner city: Paternal participation and public policy. In W. Marsiglio (Ed.), Fatherhood: Contemporary theory, research, and social policy (pp. 119147). Thousand Oaks, CA: Sage. 
Garcia Coll, C., Lamberty, G., Jenkins, R., McAdoo, H. P., Crnic, K., Wasik, B. H., \& Garcia, H. V. (1996). An integrative model for the study of developmental competencies in minority children. Child Development, 67, 1891-1914.

Graefe, D., \& Lichter, D. (1999). Life course transitions of American children: Parental cohabitation, marriage and single motherhood. Demography, 36, 205-217.

Grolnick, W. S., \& Slowiaczek, M. L. (1994). Parents' involvement in children's schooling: A multidimensional conceptualization and motivational model. Child Development, 65, 237-252. Harris, K. M., \& Morgan, S. P. (1991). Fathers, sons and daughters: Differential paternal involvement in parenting. Journal of Marriage and the Family, 53, 431-444.

Hernandez, D. C., Coley, R. L., \& Morris, J. E. (2003, April). Father and mother reports of father involvement used to predict child outcomes. Poster presented at the biennial meeting of the Society for Research in Child Development, Tampa, FL.

Hofferth, S. L. (2003). Race/ethnic differences in father involvement in two-parent families. Journal of Family Issues, 24, 185-216.

Hofferth, S. L., Pleck, J., Stueve, J. L., Bianchi, S., \& Sayer, L. (2002). The demography of fathers: What fathers do. In C. S. Tamis-LeMonda \& N. Cabrera (Eds.), Handbook of father involvement: Multidisciplinary perspectives (pp. 63-90). Mahwah, NJ: Erlbaum.

Hoy, W. K., \& Woolfolk, A. E. (1993). Teachers' sense of efficacy and the organizational health of schools. Elementary School Journal, 93, 355-372.

Inhinger-Tallman, M., Pasley, K., \& Buehler, C. (1993). Developing a middle-range theory of father involvement postdivorce. Journal of Family Issues, 14, 550-571.

Jarrett, R. L., Roy, K. M., \& Burton, L. M. (2002). Fathers in the "Hood": Insights from qualitative research on low-income African-American men. In C. S. Tamis-LeMonda \& N.

Cabrera (Eds.), Handbook of father involvement: Multidisciplinary perspectives (pp. 211-248).

Mahwah, NJ: Erlbaum.

Kelley, M. L., Smith, T. S., Green, A. P., Berndt, A. E., \& Rogers, M. C. (1998). Importance of fathers' parenting to African American toddlers' social and cognitive development. Infant Behavior and Development, 21, 733-744.

Lamb, M. E. (2000). The history of research on father involvement: An overview. Marriage and Family Review, 29, 23-42.

Lamb, M. E. \& Tamis-LeMonda, C. S. (2004). The role of the father: An introduction. In M. E. Lamb (Ed.), The role ofthe father in child development (pp. 1-31), New York: Wiley. Lewis, C. (1997). Fathers and preschoolers. In M. E. Lamb (Ed.), The role of the father in child development (pp. 121-142). New York: Wiley.

Mackey, W. C. (1998). Father presence: An enhancement of a child's well-being. The Journal of Men's Studies, 6, 227-244.

Marsiglio, W., Amato, P., Day, R., \& Lamb, M. E. (2000). Scholarship on fatherhood in the 1990s and beyond. Journal of Marriage and the Family, 62, 1173-1191.

Marsiglio, W., Day, R., \& Lamb, M. E. (2000). Exploring fatherhood diversity: Implications for conceptualizing father involvement. Marriage and the Family Review, 29, 269-293.

Martin, R. P. (1988). The Temperament Assessment Battery for Children. Brandon, VT: Clinical Psychology Publishing.

McAdoo, J. (1981). Involvement of fathers in the socialization of Black children. In H. P. McAdoo (Ed.), Black families (pp. 225-237). Newbury Park, CA: Sage Publications. 
McAdoo, J. (1986). Black fathers' relationships with their preschool children and the children's development of ethnic identity. In R. Lewis \& R. Salt (Eds.), Men in families (pp.169- 180). Beverly Hills, CA: Sage Publications.

McBride, B. A., \& Rane, T. R. (1998). Parenting alliance as a predictor of father involvement: An exploratory study. Family Relations, 47, 229-236.

McDowell, D. J., Kim, M., O’Neil, R., \& Parke, R. D. (2002). Children's emotional regulation and social competence in middle childhood: The role of maternal and paternal interactive style. Marriage \& Family Review, 34, 345-364.

McLanahan, S., \& Carlson, M. S. (2004). Fathers in fragile families. In M. E. Lamb (Ed.), The role of the father in child development (pp. 368-396), New York: Wiley.

Meisels, S. J. (1999). Assessing readiness. In R. C. Pianta \& M. Cox (Eds.) The transition to kindergarten: Research, policy, training, and practice. Baltimore: Paul Brookes Publishers. Mendez, J. L., Fantuzzo, J., \& Cicchetti, D. (2002). Profiles of social competence among lowincome African American preschool children. Child Development, 73, 1085-1100.

Mendez, J. L., McDermott, P., \& Fantuzzo, J. (2002). Identification and promotion of African American children's social competence: Developmental and contextual considerations.

Psychology in the Schools, 39, 111-123.

Moynihan, D. P. (1965). The Negro family: The case for national action. Washington, DC:

Office of Policy Planning and Research, United States Department of Labor.

National Education Goals Panel. (1997). The national education goals report: Building a nation of learners. Washington, DC: National Education Goals Panel.

Palkovitz, R. (1984). Parental attitudes and father's interactions with their 5-month-old infants. Developmental Psychology, 20, 1054-1060.

Parke, R. D. (2002). Fathers and families. In M. Bornstein (Ed.), Handbook of parenting: Being and becoming a parent (pp. 27-74). Mahwah, NJ: Erlbaum.

Pleck, J. H. (1997). Paternal involvement: Levels, sources, and consequences. In M. E. Lamb (Ed.), The role of the father in child development (pp.66-103). New York: Wiley.

Pleck, J. H., \& Masciadrelli, B. P. (2004). Paternal involvement by U.S. residential fathers: Levels, sources, and consequences. In M. E. Lamb (Ed.), The role of the father in child development (pp. 222-271), New York: Wiley.

Pleck, E. H., \& Pleck, J. H. (1997). Fatherhood ideals in the United States: Historical dimensions. In M. E. Lamb (Ed.), The role of the father in child development (pp.33-48). New York: Wiley.

Popenoe, D. (1996). Life without father. New York: Free Press.

Raver, C. C., \& Zigler, E. F. (1997). Social competence: An untapped dimension in evaluating Head Start's success. Early Childhood Research Quarterly, 12, 363-385.

Roggman, L. A., Fitzgerald, H. E., Bradley, R. H., \& Raikes, H. (2002). Methodological, measurement, and design issues in studying fathers: An interdisciplinary perspective. In C. S. Tamis-LeMonda \& N. Cabrera (Eds.), Handbook of father involvement: Multidisciplinary perspectives (pp. 1-30). Mahwah, NJ: Erlbaum.

Sameroff, A. J., \& Fiese, B. H. (2000). Transactional regulation: The developmental ecology of early intervention. In J. P. Shonkoff \& S. J. Meisels (Eds.), Handbook of early childhood intervention ( $2^{\text {nd }}$ ed., pp. 135-159). New York: Cambridge University Press

Sanderson, S., \& Thompson, V. L. (2002). Factors associated with perceived paternal involvement in childrearing. Sex Roles, 46, 99-111. 
Seefeldt, C., Denton, K., Galper, A., \& Younoszai, T. (1998). Former Head Start parents' characteristics, perceptions of school climate, and involvement in their children's education. Elementary School Journal, 98, 339-349.

Shannon, J. D., Tamis-LeMonda, C. S., London, K., \& Cabrera, N. (2002). Beyond rough and tumble: Low-income fathers' interactions and children's cognitive development at 24 months. Parenting: Science and Practice, 2, 77-104.

Shields, A., \& Cicchetti, D. (1997). Emotional regulation among school-age children: The development and validation of a new criterion Q-sort scale. Developmental Psychology, 33, 906916.

Smith, E. P., Connell, C., Wright, G., Sizer, M., Norman, J., Hurley, A., \& Walker, S. N. (1997). An ecological model of home, school, and community partnerships: Implications for research and practice. Journal of Educational and Psychological Consultation, 8, 339-360. Spencer, M. B. (1990). Development of minority children: An introduction. Child Development, 61, 267-269.

Swanson, D. P., \& Spencer, M. B. (1991). Youth policy, poverty, and African Americans:

Implications for resilience. Education and Urban Society, 24, 148-161.

Tamis-LeMonda, C. S., \& Cabrera, N. (2002). Handbook of father involvement:

Multidisciplinary perspectives. Mahwah, NJ: Erlbaum.

Tanfer, K., \& Mott, F. (1997, March). The meaning of fatherhood for men. Presented at the NICHD sponsored conference on Fathering and Male Fertility, Bethesda, MD.

Volling, B., \& Belsky, J. (1991). Multiple determinants of father involvement during infancy in dual-earner and single earner families. Journal of Marriage and the Family, 53, 461 - 474.

Wentzel, K. (1993). About being a parent. College Park: University of Maryland, Department of Human Development.

Yeung, W. J., Sandberg, J. F., Davis-Kean, P. E., \& Hofferth, S. L. (2001). Children's time with fathers in intact families. Journal of Marriage and Family, 63, 136-154. 